\title{
Decoding Corona Conscience: Analysis from the Lens of Power Posture, Vedic Philosophy and Hindu Civilization with Reference to Nepal
}

Atindra Dahal; PhD

Author Info:

Associate Professor

Kathmandu School of Law, Bhaktapur, Nepal

\section{Corresponding Author:}

Authors

Email/Contact:

fan2mefriend@yahoo. com

\section{ABSTRACT}

Background: The world, though completely unwillingly, has been surfing with the most severely heart-rending and probably the highest form of suffering of the century called CoronaVirus (COVID-19). On very outset, this paper tries to trace a few remarkable messages that the world has to infallibly and flawlessly deduce, decode and assimilate over Corona from non-pharmaceutical, non-medical and non-military vantage points. It tries unfolding the grandeur of 'Vedic philosophy and Hindu civilization based rural life practice' in mitigating such pandemic-induced health hazards. It even assesses pros and cons of Corona in Nepal.

Method: This paper has adopted doctrinal and archival methodology. Researcher's argument is derived through the paradigm of interpretation, analogy, by juxtaposing situations, and taking references of perceptions and views expressed by various scholars, duly cited with acknowledgment. A variety of relevant and recently published works i.e. major books, pertinent articles, and frequently viewed and cited sources found in Google Scholar, SCOPUS, MedLine, academia.edu are cited considering the gravity and validity of needed content. Their insight and intuition are used to support as premise while reasoning arguments.

Result: Eventually, following propositions are drawn that: pandemic is a recurring evil; it has seriously challenged the existing notion of world power strength; it has justified that behaviors based on Vedic philosophy and Hindu civilizations are prone and proficient to prevent such infections. Besides, Corona can herald both positive and negative outcomes to Nepal, ahead.

Conclusion: This paper recommends that now all concerned authorities should delve and devise on preventing such plagues and pandemics through modifications on living manner (being aligned with Vedic Philosophy and Hindu Civilization) than being overhyped on medicines/vaccines. Power should be understood in a new way; Nepal ought not to be much pessimist in light of economic future.

Keywords: Corona, Covid-19, World power, Epidemic, Civilization.

\section{Article Info}

Scan Me for Full Text

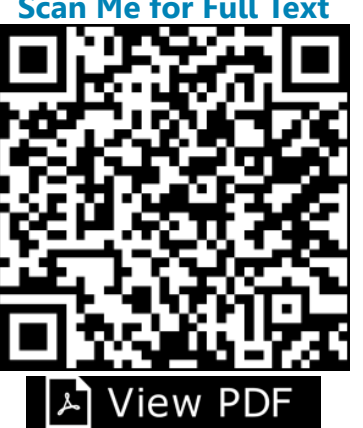
How to cite this article in Vancouver Style? doi.org/10.46405/ejms.v2i2.143

Conflict of Interest: None Declared;

\section{Disclaimer}

Received: 7 August 2020; Accepted: 1 September 2020; Published Online: 2 September 2020

Dahal A. Decoding Corona Conscience: Analysis from the Lens of Power Posture, Vedic Philosophy and Hindu Civilization with Reference to Nepal.. Europasian J Med Sci. 2020; 2(2): 124-135. https://

Source of Support: Nil

Copyright: ( 12020 by author(s). This is an open access article distributed under the terms of the Creative Commons Attribution International License 4.0 (http://creativecommons.org/licenses/ by/4.0/) which permits unrestricted use, distribution, and reproduction in any medium, provided the original work is properly cited.

\section{Publisher's Note}

The Europasian Journal of Medical Sciences (EJMS) (www.europasianjournals.org) is an official Journal of Nirvana Psychosocial Care Center \& Ressearch Institute (www.nirvanapscc.com). The Journal as well as publisher remain neutral with regards to any jurisdictional claims in any published articles, its contents and the institutional affiliations of the authors. 


\section{INTRODUCTION}

Fright of Corona is still rising worldwide and alarming the entire globe. It is increasingly becoming multi-pronged, gut-wrenching, spinechilling cum extremely heinous to all societies across the world irrespective of other disparities. The outbreak, which initiated in December 2019 by making Wuhan- a busy city of adjacent neighbor China- an epicenter has left much of the world in distress and chaos. The dismay is somewhat severe especially across Europe and Western nations and recently into India as well. Despite the utmost extent of human's most distinct dexterity and discerningly judicious deeds on obvious attempts of detaining it, the world has modicum success and uptick achievement in its visible control. All the countries globally are agonized and tortured at different but highly difficult scales. Global lockdown or various other restrictions on ordinary life have been amounting further to fuel the silence. News reports that relatively few infections have occurred in Africa and rural lives of South Asian nations. But the possibility of uncontrolled situation at any juncture of time can't be overlooked as city or crowded areas are becoming more vulnerable to this potential risk. Hence, being careful in taking precautionary measures seems strong way to avoid the possible toll. However, this predicament should not be treated only as a health issue or virus-based infection.

Covid-19, besides being a serious and severe challenge in public health, has obligated the world to assimilate a number of sheer different and significant messages regarding socio-political compass and livelihood tendencies regarding the quest on vectors of quality life and fine-tuned fabrics of society. Thus, decoding such messages for scholarly audits and updates in sphere of the existing knowledge can be a justifiable academic engagement.

Rationale of Study: COVID crisis has been heavily treated as health problem; and, globally, medical inputs have been solicited then attempted. But besides medical and pharmaceutical inquiry, Vedic philosophy and Hindu civilization may shed million dollar insights to substantially cure such obnoxious pandemic and set worthy orientations for healthy and infection free life. Thus blending of and bonding between thrust of public health science and practices derived from Vedic philosophy and Hindu Civilization makes a good sense. It even adds new insight into the existing knowledge. The discussion of paper even may assist concerned authorities for formulating better policies in quest of quality public health as well as raise level public awareness too. This enables readers to have multiple interpretations over Corona crisis regarding power status and prospects in Nepal.

\section{Aims and Objectives of Study}

This study primarily aims at evaluating Corona crisis non-medically through the lenses of power posture, Vedic Philosophy and Hindu Civilization with reference to Nepal. Further in, it expects: to explain that Covid-19 crisis is not a brand new episode; to highlight the way how concept of power status has endangered due to this crisis; to justify that living manners based on Vedic Philosophy and Hindu Cultivation are the best strategies to prevent such pandemics over any medication; and to project pros and cons of Corona in Nepal.

\section{FINDINGS}

\section{A. Covid-19 is not a New Version}

History records that a pandemic named Spanish Cholera, which is often differently termed as as 'Spanish Flu' by Tsoucalas et al.', 'Mother of All Influenzas' by Taubenberger et al. ${ }^{2}$, 'Killer Flu' by $\mathrm{Hall}^{3}$, and 'Deadliest Plague' by Barry', suffered the world and humankind most severely shortly after end of the First World War. Spinney ${ }^{5}$ estimates approximately 500 million deaths worldwide due to that however some other reports read higher graph having approximately 750 million ends at all. The pandemic, which had caused the toll of about four percent people among the estimated 1.2 billion populace of that time, is considered to have been the biggest disaster so far of all the time. As Humphreys ${ }^{6}$ comes with detailed account, it had many waves and rounds; and the very first one, which broke out in Europe in August 1918, was called 'three day flu'. Another pernicious plague named 'Black Death' is also supposed to have cost many lives during $14^{\text {th }}$ century however very less amount of authenticate literature are accessible in this regard.

The world had been perennially infected with such a variety of viruses, even in the short past; those were in clear sight and are in vivid memory of this generation people as well. AIDS (1990), Anthrax (2001), SARS (2003), Bird Flu (2005), Swine Flu (2009), Ebola (2014), and Zika (2016) were constant witness of bacterial infections globally. These all infections too had continued as verified 
versions of the same plague of 1918 as Worobey et al. ${ }^{7}$ have often claimed. Naming it as 'W curve' strategy, they find series of such influenzas to be potentially risky for people with vulnerability and sub-optimal immunity. Nonetheless, these viruses were slightly territorial. It is the only time that the terror has ever been created globally. However, the symptoms and characteristics of those infections are relatively similar. Gostic at el. ${ }^{8}$ regard them mostly resulting in respiratory problem and multiorgan failure. In a separate study, Taubenberger et al. ${ }^{9}$ have mentioned that 'mixed bacterial infection that included pneumococcus', which is much identical with Corona at present, was noticed during examination of dead soldiers of the First World War.

Such disastrous catastrophes occurred in other periods of history too, but their separate scientific and laboratory tests were not possible to identify them; and Perlman ${ }^{10}$ considers that the evolution of medicine also had an understandably low pace in that era. Unlike the recent aggressive expansion of the communication technology, which is often perceived as 'the $4^{\text {th }}$ industry' 11 or 'the government in pocket'12 or 'Rhizome'13, even the common people did not have the mass reach on the notice in that epoch. However, there are plenty of references in history regarding epidemics or choleras. Many historians have reported that such incidents had hard hit in Nepal as well in 1830 and 1920 BS respectively.

Exactly a century later of Spanish flu- for which Humphries ${ }^{14}$ had called the last flu hoping that miracle of science on public health would take rest in control but Fedson ${ }^{15}$ would deny the impossibility of recurrence then rather had claimed it to be excessively age-specific with exorbitantly huge morality rate- terror of Corona virus is rampant and the tide is swiftly rising. A country which illogically and irrationally was in hurry to boast pride and arrogance by tagging it Chinese Virus and was arrogantly claiming that his country was not made for lock-down, which has been the most universal and pragmatic methods so far as Dineros and Dipasupilo $^{16}$ state, has undergone somewhat the hardest hit now. In terms of both speed and volume, the United States is championing in the first place even in this deadly disaster. Even though Resnick ${ }^{17}$ had appraised the model of lockdown as imitable one, president Trump was most inconsiderate and ruthless to berate China, being carefree to adopt any preventive measures as advised by various authorities.
Theorem on population, endorsed by Malthus ${ }^{18}$, claims that such a calamity and pandemic would be regular and automatic natural phenomena. He writes, "I should expect, therefore, that those countries where subsistence was increasing sufficiency at times to encourage population but not to answer all its demands, would be more subject to periodical epidemics than those where the population could more completely accommodate itself to the average produce (p. 39)", and reinforces a notion that nature itself balances exorbitantly ballooning and burgeoning population through such pitfalls or calamities. Knootz ${ }^{19}$ passes prophesy of devastating infection, around 2020, of the virus called 'Wuhan-400' from Wuhan. He writes 'Wuhan 400 is a perfect weapon. It afflicts only human beings. No other living creature can carry it (p. 183)'. North ${ }^{20}$ also forecasts identical assessment on bewildering the world and chaotic life. Constant researches on Molecular Science, Nuclear Cell and Virology Studies have shown that such epidemics, having identical feature and nature, had spread around the world and had caused havoc intermittently. Ladnmark studies ${ }^{21}, 22$, ${ }^{23}$ also note critical impacts on global health and cruel hit on public livelihood because of series of such epidemics and pandemics across the globe. The heart-rending work of the ancient philosopher Sophocles ${ }^{24}$ refers to the brutal pandemic right immediately after the King Oedipus's coronation. In the twentieth century, Camus's masterpiece ${ }^{25}$ has been a poignant explanation as the Algerian city Oran reels under earth-shattering and backbreaking pandemic eventually causing an inexplicable human toll.

This invisible catastrophe, which has heavily devastated the world now, has not ravaged Nepal beyond control yet. Recent Study ${ }^{26}$ also regards the situation unbelievably low initially despite 'sharing northern border with' and 'having highest influx of tourists during February and December 2020 from' China, the epicentre of virus. It is golden privilege for serious research along with smart news for selfesteem and self-satisfaction. We have not been a seriously infected country so far since the most of confirmed cases are noticed on citizen who are recent returnees from abroad. However, the horrors of the situation can be further frightening; therefore, Ashim et al. ${ }^{27}$ write 'it is difficult to predict the severity of the outbreak (p. 818)'.

Human generated issues like politics, religion, profession, position, money divide themselves into different stratifications. According to Seppal28, 
natural disasters or other types of problems unite the commoners and that is for social connection as humans are primarily social animal. A new study from Von Dawans et al. ${ }^{29}$ suggests that acute stress may actually lead to greater cooperative, social, and friendly behavior, even among humans. They feel that the stressed humans are more social. Alike in the wake of earthquakes, blockade, cartographic aggression, now, the Corona fright has resulted tremendous internal unity along with mass support and adherence to the government.

Therefore, such possibilities, whether human or natural, are regular cycle. Precaution to prevent such haphazard and pandemonium is the key concern than any medication. On note of being visibly fragile and not having the adequate infrastructure, people in Nepal and everyone, as Chalise $^{30}$ urges, should support and adhere to the government's call to ensure greater safety during pandemic. If the situation is out of control, no entity may be functional, and south Asia seems being vulnerable. We must assimilate the truth that the self security amounts the security of whole. It must be overcome with collective caution, active alertness and remarkable restraint. Such pandemics are regular happenings than any brand new catastrophe. All must be prepared in the same way and help others too accordingly however we are often disproportionately distraught.

\section{B. Disproportionate Distraught}

Both the Nepalese mass and media have been disproportionately distraught and overwrought with COVID-19 pandemic. A study from Budhathoki at el. ${ }^{31}$ regards communication industry being inundated with over-exposed and inflated views and news of COVID-19. Unchained and unfettered avalanches of reporting, couple of which are apparently bogus and absolutely baseless cum mere subjective, have additionally freighted, cozened and cowed the public. As the entire society has badly bungled into this beating, the whole nation has come to arrant standstill and has been relegated to utter and utmost helplessness. Since there is rarely congruent compatibility and conciliation between cases and cautious cautions taken, possibility on government's side as of spuriously misedifying people and hedging to stymie the public stigmatization and disorder or distress- as has been widely suspected and doubted-looms large. Provided the outbreak is contained to fairly low as being reported (in case of local transmission and home-grown cases as government is stating that local transmission is only 5\%), we are incontestably, indisputably and incontrovertibly the safest ever part of the planet. Ergo, provided extreme caution is cast even sensing no any detrimental and virulent vices ahead, being profoundly panic neither shows senses and makes any manner.

Such carefree conceptions were developed massively before the infection took rapidly rising graph and swift swelling up from mid May 2020 Then, all of sudden, negative projection and pessimistic view got momentum as a report ${ }^{32}$ projected that many foreign migrants (about ten hundred thousand) would be opting to return home causing double doze disheartening dismay of COVID in-bound along with down-trending nature in remittance inflow. If the smear takes vituperative and violent spike alike in some western countriesventing and radiating aggression, pompousness and snobbery on their molecular and military opulence and abundance- our capacity and efforts go unequivocally and evidently tantamount to impossible to contain and control it. Situation has barely turned so here-so-forth. Let's still not prevaricate to self; but tergiversate truly. However, pint-sized capacity and piecemeal approach shall be no where the healing mechanism in case COVID takes a terrible turn on us. As a galvanizing upshot based on assortment of impertinent decisions, imperious hectoring, unwise initiatives, insipid cum torpid public adherence, and increasing readiness to unfold prowess to inhibit insanity, the situation might be disgustingly distressing, and beyond words and capacity too. But, situation may not be that worse as the local transmission is low and recovery ratio is about $75 \%$.

Nonetheless, the narratives of Corona, on news, debate and analysis, should not be narrowed down only on the lenses of science, health, biological casualties and diseases. Corona terror is carefully crafting and cementing a new social narrative oriented towards the empowerment of ancient Vedic Philosophy and Hindu civilization along with power posture and infodemics.

\section{The New Social Narrative}

\section{Infomedimcs}

Communication is considered as an amazing gift and optimal height of human invention in today's age. 'Today people are just a click away from any and every information ${ }^{\prime 3}$ (p. 127) justifies the mass and easy access. Bryant ${ }^{34}$, in detail, writes about interconnection of media and greatness of the 
subject; and Boyle 35 too agrees accordingly. Hence, Media ought to be regarded as understandably undeniable appendage of society and tool for updates. But many fake and bogus reports (infodemics) at this time of tragedy have to be stopped as it has cozened mass additionally. Hu et $\mathrm{al}^{36}$ also note biased, unverified and confusing news further foster in stigmatizing and terrifying people. So 'collective perceptual bias' could be generated. Series of such situation in Nepal too (about details and location of infected) has proved that misinformation or rumour mill is more damaging than lack of information at all.

Nonetheless, since social networks are main communication channels now, the concepts there on cannot be ignored at all. According to Vern ${ }^{37}$, print media along with radio and television are now mere ceremonial while social networks and online journalism have appeared as mainstream mode. Scholars $38,39,40$ regard social media as 'popular buzzword' which has forged a persuasive change in the society. Aveseh ${ }^{41}$ feels it often unsocial as well but construction of public belief is being heavily leveraged as per Jenkins et al. ${ }^{42}$ urge. Obama ${ }^{43}$ too highlights the views as 'forty or fifty years ago, that force would have been the party apparatus: the big-city bosses, the political fixers, the power brokers in Washington who could make or break a career with a phone call. Today, that force is the media (p. 64)'. The globe is having race after internet ${ }^{44}$; and so is the ground reality too. More than 5 billion people worldwide are active users of such networks. But excess and glut of such news are often confusing people, terrifying them further. Many of unverified and bogus cum spurious news intimidate mass a lot. Hence it is noted that uncontrolled and unfiltered superabundance of information shall be more killing than the lack of information does so. It even has justified the need of reasonable and regular cum rightful regulation over media, especially social media.

\section{Power Posture}

This epidemic has sufficiently questioned the world power equation. Of course, author $\mathrm{Nye}^{45}$ had already made a hint of it. Gallarotti ${ }^{46}$ too writes 'Understanding soft power is an especially important venture today (p. 3)' and considers it as smart power as well. Aligned with the essence of message, the world mass is realizing that weapon, warrior or warship don't gauge the power. Today, a question has become increasingly complex to the front of self-proclaimed powerful nations emitting arrogance and pride. What did their nuclear weapons, atomic arms, molecular reserves, chemical furnaces, long range missiles, radioactive cannons, various types of military trainings and other powerful warfare logistics help to mitigate the core crises of the world or self? All these alleged achievements, for which most nations have spent large chunks of budget, are proved absolutely futile today. No one should wage war to prove ability. Managing self is the highest aspect and huge success than winning others. The epidemic has forced everyone to assimilate this grand message. Concept of 'eventual elimination of nuclear weapons' as Shultz ${ }^{47}$ forecasts and forceful destruction on the 'value of the weapons of mass destruction' like Carus ${ }^{48}$ has imagined have been proved real.

Synchronously, Asia's lead and rising status has been adduced without flaw. The evident success story of Asian nations (like China, South Korea, Japan and so on) to contain and control the infection with minimal loss compared to western nations has unfolded and hailed brand new message of electrifying edification and strength. The global gumption has been drawn imprecise and hazy. Here too, one more dimension got added into Post American World that Zakaria ${ }^{49}$ has assumed or Friedman ${ }^{50}$ has shed light on changing nature in the world. The notion of Asian century in terms of success has once been set up again as controlling COVID in many Asian nations didn't become challenging alike most western nations.

As per studies from Chandy and Gertz ${ }^{51}, 93$ percent of global poverty reduction has taken place in Asian countries. Development dimension has been best and impossible to second so far. Separate studies ${ }^{52,53}$ infer a fact that Asia is lead in progress and broadness of Happiness and Mental equanimity as well. Kanbur and Spence ${ }^{54}$ feel Asia as hotspot with the highest ever form of equality of opportunity and with very fair chance to everyone to participate. Hence, it succeeded to trigger to uproot the social and economic tensions normally amounted by inequality. Bourguignon et al. ${ }^{55}$ note Asia being perpetuated by cultural mechanism and success as well as being leader in global common issues alike Angel et al. ${ }^{56}$ aver that urban expansion has taken an unbeatable and undefeatable speed in Asia continent. Corona crisis as well, since most Asian nations tried controlling it with minimal loss compared to most western nations, has once brought Asian nations in front among others in course of proving excellence. 
Despite growing challenges and risks looming large, the current government's preventive measures are quite commendable in course of containing the spread as there is no exact medication or vaccine yet. Citizens' attention to their own security, if possible to care others as well to some extent, amounts for security of whole populace in the nation. However, this fear has to be gauged in a different debate of, whether medicine or manner, basing it into Vedic Philosophy and Hindu Civilization.

\section{Medicine versus Manner}

Non-violence, as Ahimsha, what Ackerman and Duvall ${ }^{57}$ regard as 'most powerful drive for $21^{\text {st }}$ century' and health, as concept of Arogya, are the most important aspects explained in Vedic philosophy. Various scholars ${ }^{58,59,60}$ too derive and deduce the uniformed conclusion as nonviolence is the key essence and noble quest of this century. Health is a very valuable asset. Victory over nature is not possible. The scientific basis of the ancient eternal contemplation and practice of worshipping nature, rivers, streams, animals and vegetations has now become apparent to the world. The great importance of ancient Eastern Vedic philosophy, which is 'core solution of all prevalent evils' as Sangroula ${ }^{61}$ deems, in living practices has now come to the light. The shining brightness of the practices such as greeting with Namaskar instead of handshake or hugging, residing at a certain distance, wearing another garment after coming from out, and changing clothes at meal timewhat the so-called modernist society often would rate as conservative Hindu course- is now proved paramount.

Some irrational and arrogant western authors would periodically write that Asia is the land of the poor and filthy. Cold, cough, cholera and epidemics are the drink of Asians and Africans, they would vehemently vomit. Ghani ${ }^{62}$ regards the sub-region as a whole: is home to the largest concentration of poor people globally, suffers from wide gender disparities, and rates low in human development indices; Kown ${ }^{63}$ tags it economically poor. $\mathrm{Nabi}^{64}$ blames as gross education enrolment rate, average years of schooling, indicator of trainability of workers are considerably lower among others. The scholarly engagements of such a handful of Western literary figures are/were centered on projecting the people of Asia and Africa as rude, wild, inhuman, underdeveloped, and hateful. People living there had/have to imitate western way of life to civilize themselves, they would love to spread message. Reinert ${ }^{65}$ names most of these as country at take-off stage. The Corona pandemic has even given stern repercussions to those who produce/d prejudicial knowledge to extend violence. To bathe in swimming pools brim of spit, coughs and urine, to use paper after passing toilet, baking bread instead of meal with lentil vegetable pickles, hanging eclectic bulb on a plastic tree instead of a real lamp (diyo) at basil plant have been proved to be pseudo and senselessly hollow. The futility within the pretext called modernity, as Becker-Ho and Debord ${ }^{66}$ elaborate, is all exposed. Latour ${ }^{67}$ regards many people falling victim of their so-called success trap in course of striving for fake modernity. Being aligned with the confession, even the message that 'Eastern Vedic Philosophy, Hindu civilizations and traditions are/were scientific in every way' is hailed on the ground. It also has become apparent that the city could not ensure security credibility to people.

Industries like fashion, entertainment, technology, automobiles, and tourism go first and fast prone to crash. Even during this pandemic, Khadka et al. ${ }^{68}$ state that tourism has come to complete standstill causing serious curtail in employment and income generation as well; entertainment and automobiles sectors too surf under a sordidly hard hit. Ying et al. ${ }^{69}$ too draw identical inference in Chinese context. Among tourism relying nations, as studies of $\mathrm{Coke}^{70}$, most are the small economies thus go under chronic deficit whereas Zaril and Aydiner-Avsar ${ }^{71}$ find females surfing under relatively severe pressure. However, Agriculture, since suffered nowhere, is once proved that it is the mainstay and the prime necessity. The significance of the message, though originally in form of overtly romanticized prophesy, from the author Buck ${ }^{72}$, is becoming ever more striking. It is also being established that yoga, meditation, and rest, which on Vedic life culture stresses, are the major rhythms of life.

Being modern means being scientific and evidencebased; but not necessarily the western. Some of mismanagements that west vaingloriously notes at us are highly scientific in many respects. Dirlik ${ }^{73}$ notes, 'a loss of consensus over the institutional and intellectual content of modernity (p. 279)' whereas Wittrock ${ }^{74}$ writes 'A society is modern if some key defining institutions and types of behaviours can be said to be modern (p. 32)'. Both the authors make hint that social constructs and global indictors of being modern should be adequately revisited. West constructed monolithic concept of modernity is not enough to gauge all dimensions and indicate true 
sense. So we have the opportunity to assimilate that we, based on Vedic philosophy and Hindu civilization, are more advanced than them, along with branding the concept to make it universal. It has even justified the practice of community-centered cooperation rather than self-seeking capitalism. It has proved that surviving self and helping others to survive as of own family member- principle of 'Basudaiba Kutumbakam'- is a heavenly blessing than by winning others through mass assassination. Therefore, the new dimension of manufacturing alternative knowledge cannot and should not be excluded from the debate over Corona.

Obviously, corona is a bacterial disease and even has cost the casualties in increasingly alarming rate. Still, more than disease, it is an unparalleled example of unscientific, arrogant and egotistical behavior and failure of social characteristics that we have promoted in the name of power, development and modernity. Behind such germicidal epidemics from time to time, there is a tremendous impact of the shady and corrupt cum senselessly arrogant living practices adopted in the name of modernity, which is myopic and mean in fact. By adopting ancient Vedic philosophy and Hindu civilization, such risks can be minimized in large.

Some of other instances of so-called modern and developed habits, contrary to Vedic philosophy, i.e. eating from same dish in group in name of intimacy; eating raw-foods; relying on junk foods, which are less pleasing and highly poisonous for body; excessively using soft drinks, which has hard hits and problem on lives; bathing on swimming pool, where all user spit, cough and urinate and so on are decaying the health hygiene then emasculating or debilitating immunity power in people; even, Ricanti ${ }^{75}$ has highlighted it. Such situations turn as easy way out for bacterial diseases cum community transmission. Such bacterial infections are common to people who are sizably abstaining from rural life, avoiding exercising, poisoning them by consuming long-term stored un-fresh cum stale vegetables and fruits that are almost decaying thus credit no resistance and immunity. Various researches from the World Health Organization along with a notable piece from Calabrese ${ }^{76}$ have also proved that such lifestyles have weakened immunity power globally.

Ancient oriental Hindu civilization and, especially, country-side living practices in Nepal and erstwhile efforts based on Vedic decorum of life seem very scientific in themselves. These exercises also appear to promote immune resistance in humans and to vanquish such bacterial infections. Ancient
Hindu civilization was outlined by being based on the teaching of the great texts such as the Vedas, Upanishads, Puranas, Dharmashastra, Ramayana, Mahabharata etc. There have been extensive studies on the scientific validity of the messages of the Vedas and other texts in home and overseas as many universities of repute have department on oriental studies besides thousand of independent researches by the scholars.

Building residence in a noticeable distance, exchanging honorary greetings only from a certain distance, eating the healthiest food produced oneself, eating meat only of the animals raised healthily by self, making toilet in a little farther away, changing clothes after arrival from outing, cleaning hands and feet before entering home, consuming only self grown organic vegetables and fruits are key features of Vedic lives and those automatically discard and discourage the bacterial transmission. In his writing as well, Tilg $^{77}$ has appreciated many of these practices as corner stone of healthy leaving.

The noble pursuit from Vedic actions i.e. the removal of germs by enameling house with cow-dung, the healthiness of the body by the consumption of oats, the restriction of germs by aroma of flowers planted at the residence premises, the flow of oxygen through planting Bar and Peeple trees in surrounding are getting now proved. Vedic practices like washing clothes in boiled water with ashes, taking dinner quite early for easy digestion, pairing meal with milk, cord or ghee, gathering family members together in food then listening to moral education were beautiful and scientific tendencies. The practice of getting up early in the morning, walking around, playing sports- which would collectively promote physical fitness and well-being- would be unique set of efforts for the quality of life. In addition to playing sports that promote physical health and wellbeing, the practice of wearing warm, full-bodied clothing to restrict chilly cold was much scientific pattern. Kapur $^{78}$ notes identical practices in many suburbs and country life in India too. These behaviors are still being proven to be the main armour of people's mental and physical health; and Bell and Jayne $^{79}$ urge for deep preference on such issues, which are the unique capitals of rural life.

Most people in rural part of Nepal have similar practices in use till now. The spread of such epidemic is always highly possible as the lifestyle in the city is vulnerable in terms of hoisting immunity. This is not just a fight with Corona; it is not easy to say that no such virus will occur soon after Corona. 
To have complete control of Corona's wrath may be an immediate achievement now, but it does not constitute a state of satisfaction for the world. For this, now, the general life-style has to adopt then integrate changes quite drastically. The ancient Vedic practices, which have been proven to increase the ability to resist such potential risks, should be followed. The present terror mayn't be just the beginning, intermittent or a temporary condition, thus mere medicine does not solve the problem of longevity.

By containing this crisis, there ought to be a confidence and assurance that the world doesn't plunge into such pitfall again. There is no shortcut clinical medicine for the horror of Corona or pandemic of other similar nature. The main necessity is to build a scientific life. The revival of the ancient scientific way of life (as per Vedic philosophy and Hindu civilization) is a major shield to defeat and distance such epidemic spreads. The drug may be transient and quick-fix; but, only the purification of the conduct is the long-lasting medicine of such 'the fear'. So, let's build virus resistant life manner by adopting Vedic philosophy and Hindu civilization based life-style than musing on mitigating it through medicine.

\section{Post-corona Projection}

The anxiety of corona virus has had a swiftly rising graph with exponentially ballooning panic and pain across the globe; and, Ramaci et al. ${ }^{80}$ note it as potentially existing to suffer people till long time. Similarly, Nepal will also definitely surf into noticeable changes in every sector of society. The greatest ever impacts will be on economic landscape of nation as Barkur and Vibha Kamath ${ }^{81}$ strongly lay focus on note of lockdown, which has been globally common practice, in India as well. It might hugely halt the inter-country import and export of necessary goods causing serious shortfall of edible items as we excessively rely on outer world for the same. A new solemn problem of stark starvation may further hit the significant quarter of citizens provided not any strong precautionary measure is adopted anon.

Bastola et al..$^{82}$ remark that a serious negative jolt may be experienced into whole national treasury as it is disproportionally relying on remittance; and the inflow of it may get stumbling block because of stagnated and stigmatized life globally. The possibility of many migrant workers losing job undeniably persists prolonged. It hits hardest on the economy of Nepal. Revenue generation may slide towards downward trajectory. The graph of inflation, in house, may set a new record owing to devaluation of the currency.

People practicing seasonal and short-term migration for foreign employment along with people residing in various other nations of world may voluntarily prioritize to return and stay in home. Goldmann \& Galea ${ }^{83}$ suspect that people may undergo a huge physiological problem cum mental health or disorder as Lai et al ${ }^{84}$ project it in terms of migrant workers in this regard. That takes the job market of nation into compelling pressure to adjust them. Many people working here may lose jobs. Startup companies might turn to liquidation. Areas like tourism, auto-mobile, fashion and real-estate may take somewhat longer time span to revive the pace of its regular cum seamless operation.

Besides dreadfully dark sides, the most ever pleasing and appealing aspect is that it might revive and revitalize the agricultural sector of Nepal with an added modernization and commercialization. Many returnees from overseas may embark unique and multipronged profitable entrepreneurships here in home. To make people the biggest beneficiary, Poudel et al. ${ }^{85}$ hint for huge scope in this area. Various new businesses and industries may take proactive life into corporate fraternity and front. More employment opportunities will be generated. Revenue and excise duty may set new record. Capital flow towards nation may take unpremeditated height from those who muse to stay here permanently, leaving their abroad stations. IT industries might set new record in volume and velocity of business. People may start working from home, resulting into time saving mode. Education can be accessible even for those who don't have time to attend offline classes. International resource persons can be introduced in the class. Webinar ensures platform to many people as speaker. Kimrey ${ }^{86}$ highlights on how the crisis can be converted into cosmopolitan opportunity; and, we ought to act on the spirit.

Now, China will have great positive upshot in economy. Though being the first country to face merciless strike and sufferings from virus, now, China has healed self the best and arrant. The rest of world is relegated to sheer helplessness. When rest of the world succeeds in beating pandemic and comes to the point of resuming normal life, most will have already lost their economic compass. China will be a single and superlative source for global market then. That business height, what China gets and earns, can generate spill-over effect to Nepalese industries and market as well. 
Every crisis unleashes countless opportunities too; let's think positive!

\section{WAY FORWARD}

Vedic Philosophy and Hindu Civilization based following manners (along with stern restriction on few of so-called modern practices) must be revived ahead in our living practices.

1. Assimilating Ahimsha and Arogya as key power than nuclear arms and atomic ammunitions,

2. Greeting with Namaskar instead of handshake or hugging,

3. Building residence at a certain distance,

4. Changing garment at meal time,

5. Refraining from bathing in swimming pools as those are often brim of spit, coughs and urine,

6. Stopping to use paper after passing toilet,

7. Correcting on enjoying bread instead of nutritious meal with lentil, vegetable, and pickles,

8. Pausing in hanging eclectic bulb on a plastic tree instead of a real lamp (diyo) at basil plant,

9. Reviving country-based rural life civilization,

10. Considering agriculture as prime economic base,

11. Making yoga, meditation, and rest as the major rhythms of life,

12. Practicing the principle of 'Basudaiba Kutumbakam',

13. Invalidating eating from same dish in group in name of intimacy,

14. Sizably incorporating regular exercises,

15. Regularly consuming fresh and organic vegetables,

16. Eating meat only of the animals raised healthily by self,

17. Making toilet in a little farther away,

18. Changing clothes after arrival from outing,

19. Cleaning hands and feet before entering home,

20. Consuming only self grown organic vegetables and fruits,

21. Removing germs by enameling house with cow-dung,

22. Maintaining healthiness of the body by the consumption of oats,

23. Restricting germs by aroma of flowers planted at the residence premises,

24. Ensuring the flow of oxygen through planting Bar and Peeple trees in surrounding,

25. Washing clothes in boiled water with ashes,

26. Taking dinner quite early for easy digestion,

27. Pairing meal with milk, cord or ghee,

28. Gathering family members together in food time then listening to moral education,

29. Getting up early in the morning, walking around, and playing sports,

30. Wearing warm, full-bodied clothing to restrict chilly cold.

\section{CONCLUSION}

Hence COVID 19 is not mere a viral disease, it is perfect blend of various messages, for which the world has pressing obligation to unequivocally agree with. It has made people realize that such infections in form of pandemics are recurrent in nature. Simultaneously, the overrated success indicated by military power and nuclear aggrandizement is futile in present world. It has even once come to the front that Vedic philosophy and Hindu civilization had already orientated people for such scientific living, which could argument humankinds' immunity and prevent such infections. So, adopting those manners of public life could be wise step to remain safe and ensure better public health. Corona once more has unmasked the beauty and science embedded with Vedic philosophy and Hindu civilization along with posing both pros and cons to Nepal.

\section{REFERENCES}

1. Taubenberger JK, Reid AH, Lourens RM, Wang R, Jin G, Fanning TG. Characterization of the 1918 influenza virus polymerase genes. Nature. 2005; 437: 889-893. https://doi.org/10.1038/nature04230. PMid:16208372

2. Taubenberger JK, Reid AH, Lourens RM, Wang R, Jin G, Fanning TG. Characterization of the 1918 influenza virus polymerase genes. Nature. 2005; 437: 889-893.

3. Hall Bridget. Killer flu swept around the globe in 1918. Lakeland Ledger. USA: Brian Burns. (Date unknown)

4. Barry JM. The Great Influenza: The Epic Story of the Deadliest Plague in History. New York: Viking; 2004.

5. Spinney Laura. Pale Rider: The Spanish Flu of 1918 and How It Changed the World. USA: Amazon; 2017.

6. Humphreys Margaret. The influenza of 1918: 
evolutionary perspectives in a historical context. Evolution, Medicine, and Public Health. 2018: 219-229 doi:10.1093/emph/ eoy024. $\quad$ https://doi.org/10.1093/emph/eoy024. PMid:30410762 PMCid:PMC6218637

7. Worobey M, Han G-Z, Rambaut A. Genesis and pathogenesis of the 1918 pandemic H1N1 influenza: A virus. Proc Natl Acad Sci. 2014; 111: 8107-12. https://doi.org/10.1073/pnas.1324197111. PMid:24778238. PMCid:PMC4050607

8. Gostic KM, Ambrose M, Worobey M, LloydSmith JO. Potent protection against H5N1 and H7N9 influenza via childhood hemagglutinin imprinting. Science. 2016; 354:722-726. https://doi.org/10.1126/science.aag 1322 PMid:27846599 PMCid:PMC5134739.

9. Taubenberger JK, Reid AH, Fanning TG. The 1918 influenza virus: A killer comes into view. Virology. 2000; 5, 274:241-5. https://doi.org/10.1006/ viro.2000.0495. PMid:10964767.

10. Perlman RL. Evolution and Medicine. Oxford: Oxford University Press; 2013.

11. Anderson C. Makers: The New Industrial Revolution. New York: Crown Publishing; 2012.

12. Tsiatsis Vlasios, Karnouskos Stamatis, Holler Jan, Boyle David, Mulligan Catherine. From Machineto-Machine to the Internet of Things: Introduction to a New Age of Intelligence. Amsterdam: Elsevier; 2014.

13. Carpentier N. Community media as rhizome: Expanding the research agenda. Journal of Alternative and Community Media. 2016; 1:4-6. https://doi.org/10.1386/joacm 00003_ 1.

14. Humphries MO. The Last Plague: Spanish Influenza and the Politics of Public Health in Canada. Toronto: University of Toronto Press; 2013.

15. Fedson David. Influenza, evolution and the next pandemic. Evol Med Public Health. 2018;1: 260-269. https://doi.org/10.1093/emph/eoy027. PMid:30455951 PMCid:PMC6234328

16. Dineros Kevin, Dipasupil Jan Paolo. COVID-19 Crisis Management and Prevention Plan. 2020. Retrieved March 21, 2020. [Link]

17. Resnick Brian. Italy and China used lockdowns to slow the coronavirus: Could we? $V O X$. 2020. Retrieved 25 March 2020. [Link]

18. Malthus Thomas Robert. An Essay on Principle of Population. London: J. Johnson; 1798.

19. Koontz Dean. Eyes of Darkness. USA: Project
Books; 1981.

20. North Claire. The End of the Day. UK: Hachette; 2017.

21. Madad Syra S. Bioterrorism: An emerging global health threat. Journal of Bioterrorism and Biodefense 5. 2014; no, 1. https://doi.org/10.4172/21572526.1000129

22. Morens DM, Fauci AS. Emerging infectious diseases: Threats to human health and global stability. PLoS Pathog. 2013; 9(7): e1003467. https://doi.org/10.1371/journal.ppat.1003467. PMid:23853589 PMCid:PMC3701702

23. Clinton Chelsea, Sridhar Devi. Governing Global Health. New York: Oxford University Press; 2017.

24. Sophocles. Oedipus Rex. Greece; 429BC.

25. Camus Albert. The Plague. France: Gallimard; 1947.

26. Shrestha Ranish, Shrestha Sunil, Khanal Pratik, KC Bhuwan. Nepal's first case of COVID-19 and public health response. Journal of Travel Medicine 27(3). 2020; February. https://doi.org/10.1093/jtm/ taaa024. PMid:32104884 PMCid:PMC7107523

27. Asim M, Sathian B, Teijlingen E van, Mekkodathil A, Subramanya SH, Simkhada P. COVID-19 pandemic: Public health implications in Nepal. Nepal J Epidemiology. 2020; 10 (1): 817820. https://doi.org/10.3126/nje.v10i1.28269 PMid:32257511 PMCid:PMC7112957.

28. Seppal Emma. How the stress of disaster brings people together. Scientific American Mind. 2006. USA.

29. Von Dawans B, Fischbacher U, Kirschbaum C, Fehr E, Heinrichs M. The social dimension of stress reactivity: Acute stress increases pro-social behavior in humans. Psychological Science. 2012. DOI: $\quad 10.1177 / 0956797611431576$. https://doi. org/10.1177/0956797611431576. PMid:22593119

30. Chalise Hom Nath. COVID-19 situation and challenges for Nepal. Asia-Pacific Journal of Public Health - 2020. https://doi. org/10.1177/1010539520932709. PMid:32545991

31. Budhathoki P, Shrestha DB, Khadka S, Giri S. COVID-19 status in Nepal and the way forward. Europasian J Medical Sci.2020;2 (Covid-19 Special Issue):1.5. https://doi.org/10.46405/ejms.v2i2.75

32. Potential impact of COVID-19 on Nepalese economy. Nepal: Reanda; 2020.

33. Shing Gaurav, Pandey Nity. Role and impact of media on society: A sociological approach with 
respect to demonetisation. International Journal of Research in Humanities, Arts and Literature 2017; 5(1):127-136.

34. Bryant J. Handbook of Sports and Media. Taylor \& Francis Group; 2006.

35. Boyle R. H. R. Power Play: Sport, the Media and Popular Culture. Edinburgh University Press; 2009.https://doi.org/10.3366/ edinburgh/9780748635924.001.0001.

36. $\mathrm{Hu}$ Zhiwen, Yang Zhongliang, Li Qi, Huang Yongfeng. Infodemiological study on COVID-19 epidemic and COVID-19 infodemic. China: National natural foundation. 2020. https://doi. org/10.20944/preprints202002.0380.v3

37. Vern Kelly. Celeb 2.0: How Social Media Foster Our Fascination with Popular Culture. USA: Praeger; 2012.

38. Burkhardt A. Social media: A guide for college and university libraries. College \& Research Libraries News. 2010; 71:10-24. https://doi.org/10.5860/ crln.71.1.8302

39. Van der Bank C.M. The impact of social media: Advantages or disadvantages. African Journal of Hospitality, Tourism and Leisure. 2015; 4 (2).

40. Zeng B, Gerritsen R. What do we know about social media in tourism? A review. Tourism Management Perspectives, 2014; 10. https://doi.org/10.1016/j. tmp.2014.01.001

41. Aveseh Asough. The impact of social media on journalism ethics. Social Media and Ethics. 2012. Center for International Media Ethics (CIME), December.

42. Jenkins H, Ford S, Green J Spreada Ble Media Creating Value and Meaning in a Networked culture. USA: New York University Press; 2013

43. Obama, B. The Audacity of Hope: Thoughts on Reclaiming the American Dream.USA: Canongate Books Ltd; 2006.

44. Nakamura Lisa, Chow-White Peter A. Race after the Internet. Routlege; 2012. https://doi. org/10.4324/9780203875063

45. Nye Joseph S. Soft Power: The Means to Success in World Politics. USA: Public Affairs; 2007.

46. Gallarotti Giulio M. Soft power: What it is, why it's important, and the conditions under which it can be effectively used. Working Paper. Division II Faculty Publications. 2011; 57.

47. Shultz George P, Perry William J, Kissinger Henry A, Nunn Sam. A world free of nuclear weapons.
The Wall Street Journal, January 4, 2007; A15.

48. Carus W. Seth. Weapons of mass destruction. Occasional Paper 8. 2012. Washington, DC: NDU Press. https://doi.org/10.21236/ADA577317.

49. Zakaria Fareed. The Post-American World. USA: W. W. Norton \& Company; 2008. https://doi.org/10.1111/j.1540-5842.2008.00993.x

50. Friedman Thomas L. The World is Flat: A Brief History of the Twenty-first Century. New York: Farrar, Straus and Giroux; 2006.

51. Chandy L, Gertz G. Poverty in the Numbers: The Changing State of Global Poverty from 2005 to 2015. Washington, DC: Brookings Institution; 2011.

52. Dolan Paul, Layard Richard, Metcalfe Robert. Measuring Subjective Well-Being for Public Policy: Recommendations on Measures. London: Centre for Economic Performance, London School of Economics; 2010.

53. Stiglitz JE, Sen A, Fitoussi JP. Report by the Commission on the Measurement of Economic Performance and Social Progress. Paris: OECD; 2010.

54. Kanbur Ravi, Spence Michael. Equity and Growth in a Globalizing World. Washington, DC: Commission on Growth and Development; 2010. https://doi.org/10.1596/978-0-8213-8180-9.

55. Bourguignon Francois, Ferreira HG, Walton Michael. Equity, Efficiency and Inequality Traps: A Research Agenda. Boston: Harvard University; 2006. https://doi.org/10.2139/ssrn.902376.

56. Angel S, Sheppard SC, Civco DL. The Dynamics of Global Urban Expansion. Washington, DC: World Bank; 2005.

57. Ackerman P, Duvall J. A Force More Powerful: A Century of Nonviolent Conflict. New York: St. Martin's Press; 2000.

58. Heffron JM. The nonviolent philosophy of Daisaku Ikeda, peace \& policy. Dialogue of Civilizations for World Citizenship 8. 2003: 103-105.

59. Helvey RL. On Strategic Nonviolent Conflict: Thinking About the Fundamentals. Cambridge, MA: Albert Einstein Institution; 2004.

60. Schock K. Unarmed Insurrections: People Power Movements in Nondemocracies. Minneapolis, MN: University of Minnesota Press; 2005.

61. Sangroula Y. South Asia China Geo-ecnomics. Nepal: Lex and Juris; 2019. 
62. Ghani E. Reshaping Tomorrow: Is South Asia Ready for the Big Leap? New Delhi: Oxford University Press and World Bank; 2011.

63. Kwon JK, Kang JM. The East Asian model of economic development. Asian Pacific Economic Literature. 2011;25(2): 116-130. $\underline{\text { https://doi. }}$ org/10.1111/j.1467-8411.2011.01317.x.

64. Nabi I. Economic growth and structural change in south Asia: Miracle or mirage? Working Paper. 2010. UK: London School of Economics and Political Science.

65. Reinert ES. How Rich Countries Got Rich and Why Poor Countries Stay Poor. New York: Public Affairs; 2007.

66. Becker-Ho A, Debord G. A Game of War. London: Atlas Press; 2009.

67. Latour Bruno. We have Never Been Modern. USA: La Decouverte; 1993.

68. Khadka D, Pokhrel GP, Thakur MS, Magar PR, Bhatta S, Dhamala MK et al. Impact of Covid-19 on the tourism tndustry in Nepal. Asian Journal of Arts, Humanities and Social Studies. 2020; 3 (1): 40-48.

69. Ying T, Wang K, Liu X, Wen J, Goh E. Rethinking game consumption in tourism: A case of the 2019 Novel Coronavirus Pneumonia outbreak in China. Tourism Recreation Research. 2020. https://doi.org $\underline{10.1080 / 02508281.2020 .1743048}$

70. Coke Hamilton P. Impact of COVID-19 on tourism in small island developing states. 2020. [Link]

71. Zarrilli S, Aydiner-Avsar N. COVID-19 puts women working in SIDS tourism industry at risk. 2020. [Link]

72. Buck Pearl S. Good Earth. USA: John Day. 1931.

73. Dirlik A. Global modernity? Modernity in an age of global capitalism. European Journal of Social Theory, 2003; 6 (3): 275 - 292. https://doi. org/10.1177/13684310030063001.

74. Wittrock B. Modernity one, none or many? European origins and modernity as a global condition. Daedalus. 2000; 129 (1): 31-60. https:// doi.org/10.4324/9781315124872-2

75. Ricanati Elizabeth Hw, Golubic Mladen, Yang Dongsheng, Saager Leif. Mitigating preventable chronic disease: Progress report of the Cleveland Clinic's lifestyle 180 program. Nutrition and Metabolism. 2011; Volume 8:83. https://doi. org/10.1186/1743-7075-8-83. PMid:22112436 PMCid:PMC3264524
76. Calabrese Leonard H. Maintaining a Healthy Immune System: What You can do to Help. Cleveland, OH: RJ Fasenmyer Center for Clinical Immunology; 2017.

77. Tilg H. Diet and intestinal immunity. New England Journal of Medicine. 2012; Vol 366:181183. https://doi.org/10.1056/NEJMcibr1113158. PMid:22236230

78. Kapur Radhika. Science and technology for rural development. Acta Scientific Agriculture 3. 2019; 11: 140-144. https://doi.org/10.31080/ ASAG.2019.03.0699.

79. Bell D, Jayne M. Small cities? Towards a research agenda. International Journal of Urban and Regional Research. 2009; 33(3): 683-699. https:// doi.org/10.1111/j.1468-2427.2009.00886.x.

80. Ramaci T, Barattucci M, Ledda C, Rapisarda V. Social stigma during COVID-19 and its impact on HCWs outcomes. Sustainability. 2020; 12, 3834. https://doi.org/10.3390/su12093834.

81. Barkur G, Vibha Kamath GB. Sentiment analysis of nationwide lockdown due to COVID 19 outbreak: evidence from India. Asian Journal of Psychiatry. 2020. 51, 102089. https://doi. org/10.1016/j.ajp.2020.102118. PMid:32353826 PMCid:PMC7172837.

82. Bastola A, Sah R, Morales AJR, Lal BK, Jha R, Ojha HC et al. The first 2019 Novel Corona Virus case in Nepal. The Lancet, 2020; 20(3), 279-280. https://doi.org/10.1016/S1473-3099(20)30067-0.

83. Goldmann E, Galea S. Mental health consequences of disasters. Annual Review of Public Health. 2014; 35: 169-183. $\quad$ https://doi.org/10.1146/annurevpublhealth-032013-182435. PMid:24159920

84. Lai J, Ma S, Wang Y. Factors associated with mental health outcomes among health care workers exposed to Corona Virus disease 2019. JAMA Network Open. 2020; 3(3), e203976. https:// doi.org/10.1001/jamanetworkopen.2020.3976. PMid:32202646 PMCid:PMC7090843

85. Poudel PB, Poudel MR, Gautam A, Phuyal S, Tiwari CK, Bashyal S. COVID-19 and its global impact on food and agriculture. Journal of Biology and Today's World. 2020; 9(5), 221-225.

86. Kimrey Christopher M. Learning to See the Opportunities in Crisis and Catastrophe: A Decision Maker's Guide to the Issue-Attention Cycle. Dissertation submitted to Naval Postgraduate School, California, September; 2015. https://doi. org/10.21236/AD1009071 
